Boise State University

ScholarWorks

7-1998

Seismic Reflection Imaging of a Geothermal Aquifer in an Urban Setting

Lee Liberty

Boise State University 


\title{
Seismic reflection imaging of a geothermal aquifer in an urban setting
}

\author{
Lee Liberty*
}

\begin{abstract}
A seismic reflection survey that was conducted in downtown Boise, Idaho, to help city planners site a new well for injection of spent geothermal water illustrates some methods to safely and successfully employ a seismic reflection survey in an urban setting. The objective of the seismic survey was to estimate the depth and continuity of a basalt and rhyolite volcanic sequence. Well siting was based on geothermal aquifer depth, location of interpreted faults, projected thermal impact of injection on existing wells, surface pipe extension costs, and public land availability. Seismic acquisition tests and careful processing were used to ensure high-quality data while minimizing the potential for damage along city streets. A video camera placed in a sewer and a blast vibration monitor were used to confirm that energy from the seismic source (a 75 -in ${ }^{3}$ land air gun) did not damage nearby
\end{abstract}

buildings, street surfaces, or buried utilities along the survey lines. Walkaway seismic tests were also used to compare signal quality of the air-gun source to an explosive source for imaging targets up to $800 \mathrm{~m}$ depth. These tests show less signal bandwidth from the air-gun source compared to the buried explosive source, but the air-gun signal quality was adequate to meet imaging objectives.

Seismic reflection results show that the top of this rhyolite/basalt sequence dips $\left(\sim 8-11^{\circ}\right)$ southwest away from the Boise foothills at depths of 200 to $800 \mathrm{~m}$. Seismic methods enabled interpretation of aquifer depths along the profiles and located fault zones where injected water may encounter fracture permeability and optimally benefit the existing producing system. The acquisition and processing techniques used to locate the Boise injection well may succeed for other hydrogeologic and environmental studies in urban settings.

\section{INTRODUCTION}

The first geothermal heating district in the nation was established in Boise, Idaho, in 1892 (Wood and Burnham, 1987). Today, over 100 million gal of water are drawn annually from wells into the geothermal aquifer to provide heat to government buildings and residential homes in Boise through a distribution of more than $10 \mathrm{~km}$ of surface pipes (Rafferty, 1992). Four separate geothermal-based heating facilities are presently in operation (Figure 1), including the Boise Warm Springs Water District, the State of Idaho, the U.S. Department of Veterans Affairs, and the City of Boise systems.

In recent years, the increased rate of hot water extraction has resulted in a drop in artesian levels. The Idaho Department of Water Resources has imposed a moratorium on increased production from the geothermal aquifer until actions are taken to stabilize the system. Since the Department of Veterans Affairs and the State of Idaho already inject spent geothermal water, and the Boise Warm Springs Water
District has legal rights to the geothermal aquifer without injection of spent water (based on a historical precedent), the City of Boise and the U.S. Department of Energy have agreed to design and construct a new injection well.

To continue to develop the Boise geothermal aquifer, steps must be taken to stabilize the pressure of the system without significantly reducing the temperature of the extracted water. However, with the current practice of dumping spent geothermal water into the Boise River and extracting water faster than natural recharge, the system's ability to stabilize is greatly reduced. In addition, the spent geothermal water has a high fluoride ( $\sim 15 \mathrm{ppm})$ and thermal load. Limitations on dumping the unprocessed water directly into the river may soon be set. By adding a new injection well, the city hopes to stabilize the geothermal system and lift the moratorium imposed by the Idaho Department of Water Resources, thereby allowing more customers to have access to this potentially renewable and local energy resource. 
Two seismic reflection lines (Figure 1) were deployed to help site the new geothermal injection well. Since the footage costs for drilling match the footage costs for extending the pipes for the heating system, seismic line locations were chosen to cover an area near the existing collection and distribution system and near well control, thus placing the seismic reflection profiles in downtown Boise. A first-order goal was to estimate the depth to the geothermal aquifer along the profiles so that drilling costs associated with different sites could be identified. In addition to estimating depth to the geothermal aquifer, locating faults in the rhyolite/basalt sequence was of interest. If the injection well penetrates a fault zone, the geothermal water may circulate back to the production wells, assuming the faults act as conduits for geothermal water circulation. Also, a requirement that the injection well minimize the thermal impact on the existing production wells forced the new injection well site south of the current production field (Figure 1). The ideal site, from the city's perspective, was at the present spent geothermal water disposal site along the Boise River (Figure 1), where infrastructure and appropriate zoning already exist, but final site selection considered drilling costs (based on aquifer depth), surface pipe extension costs, land availability, thermal impact on the existing well field, and geometry of the geothermal aquifer (i.e., fault locations).

\section{GEOLOGIC FRAMEWORK}

Each geothermal production well in Boise pumps $65-75^{\circ} \mathrm{C}$ water from a porphyritic rhyolite member of the Idavada
Group, an upper Miocene volcanic and sedimentary rock assemblage (Figure 2). The rhyolite units are widespread and are suspected to extend throughout much of the Boise valley (Wood and Burnham, 1983; Clemens and Wood, 1993). The geometry of permeability in the rhyolite unit is unknown. Fracture permeability as a result of original cooling joints, flow breccia, or weathering is suspected in some wells (e.g., State of Idaho wells), whereas fractures related to faults may contribute to geothermal water circulation in other production wells (e.g., Boise city wells, Veterans Administration wells). Wedge-shaped fault blocks mapped along the Boise front exist as a result of late Cenozoic normal faulting (Wood and Burnham, 1983). These interconnected faults, ranging from a $\mathrm{N} 10^{\circ} \mathrm{W}$ to $\mathrm{N} 70^{\circ} \mathrm{W}$ orientation, provide potential avenues for lateral and vertical geothermal water circulation within the volcanic units.

The geothermal water is confined from above by a basalt, basaltic tuff, and sedimentary rock sequence. In particular, lowpermeability basaltic tuffs unconformably overlie the eroded top of the geothermal aquifer (Clemens and Wood, 1993). The upper contact to the geothermal system can be recognized by both a temperature and a static water-level increase in geothermal wells at the lower contact of the basaltic tuffs (Wood and Burnham, 1983). Miocene to Quaternary Idaho Group fluvial and lacustrine sediments unconformably overlie the basaltic tuffs and fill the western Snake River Plain Basin (Wood, 1994). Beneath the Boise downtown area, the deeper Idaho Group sediments are predominantly lacustrine

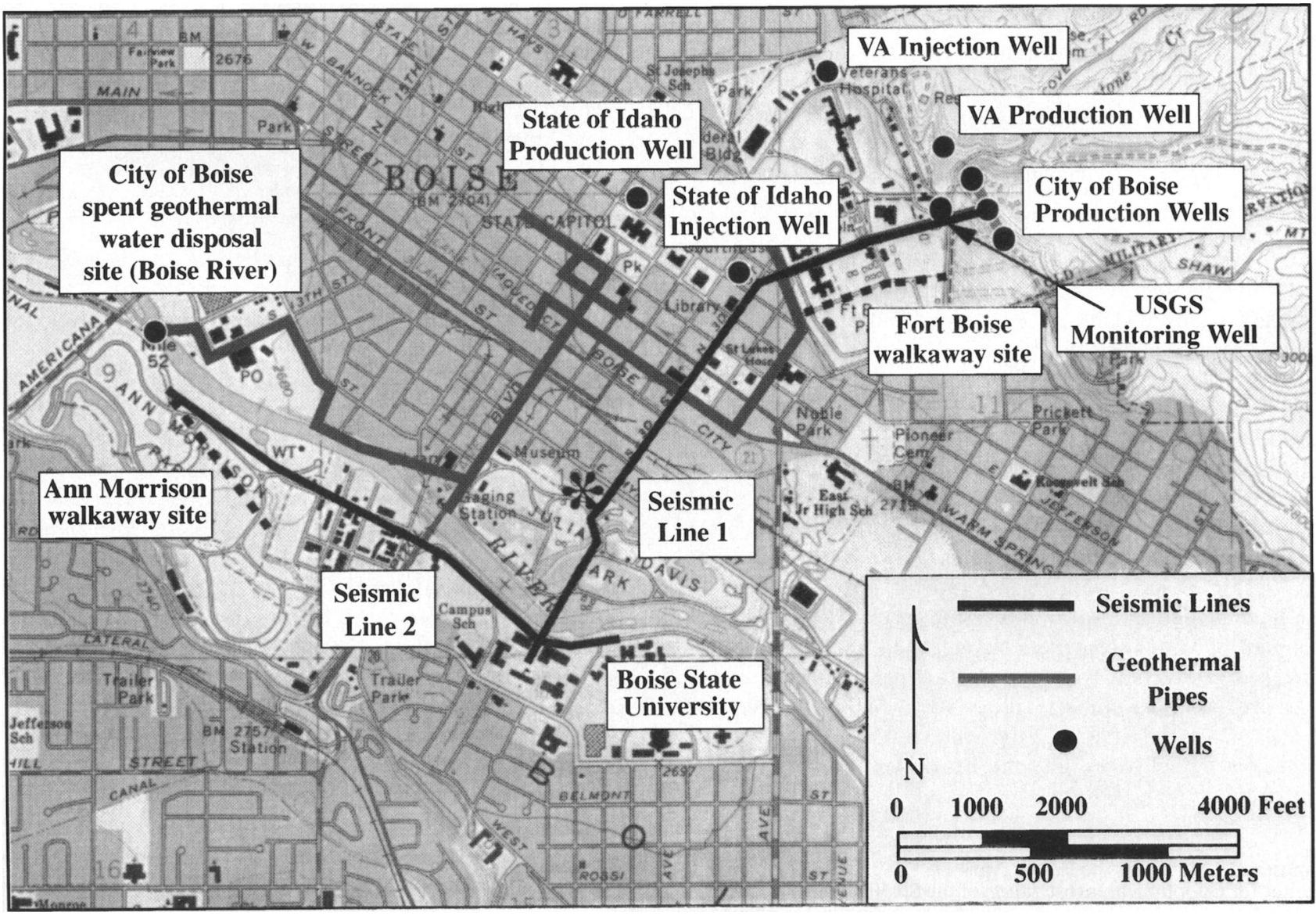

FIG. 1. Location map of study area in downtown Boise, Idaho. Seismic reflection line locations, walkaway test sites, Boise City geothermal pipes, and geothermal wells are identified. Asterisk along Line 1 represents selected injection site. 
mudstones of low permeability overlain by fluvial interbedded sands, muds, and gravels ( $\mathrm{S}$. Wood, personal communication). The deeper Idaho Group sediments contain two intercalated basalt flows (Clemens and Wood, 1993).

Below the rhyolite units are granitic rocks of the Cretaceous Idaho Batholith. Fractures in the Idaho Batholith rocks are the presumed avenue for deep circulation and natural recharge of the aquifer (Figure 3). Open fractures from late Cenozoic fault activity are a conduit for the hot water, with a moderate artesian head, into the permeable rhyolite units above (Wood and Burnham, 1983).

\section{SEISMIC METHODS}

\section{Walkaway seismic tests}

A surface seismic source was needed to acquire seismic data through downtown Boise because of restrictions on shot-hole drilling along city streets underlain by utilities. We selected a land air gun (from Bolt Technologies) as our seismic source because of its mobility, repeatability, and energy output. A swept seismic source (e.g., vibroseis or MiniSOSIE) was not selected because the required signal durations exceeded the recording capabilities of our system. We compared the air gun's energy output with a buried explosive source $(1 / 3 \mathrm{lb}$ kinestik) to determine if the signal quality of the air gun was adequate to image our target. We selected two walkaway test sites (Figure 1) at geologic end-member locations (where estimated bedrock depth was shallowest and deepest along the proposed profiles). Bedrock depths were projected from nearby geothermal wells (Figure 2) and estimates of dip for the volcanic assemblage. Results from the test site with greatest depth to bedrock
(Figure 4a) show a large-amplitude reflection package near the predicted depth to the top of the rhyolite/basalt sequence using the explosive and the air-gun sources. Although reflections from the air-gun source appear more band limited (Figure $4 \mathrm{~b}$ ), comparable reflections appear. Thus, the results of the walkaway tests indicate that both the explosive and the air-gun sources provided enough energy to image the rhyolite/basalt sequence at the end-member sites. The results also suggest that the projected depth to the upper rhyolite at the initially preferred injection site (at the present disposal site shown on Figure 1) was too deep (based on the assumption that the thickness of the upper rhyolite to upper basalt contact is constant, as shown in Figure 2). Depth to the rhyolite at the site is greater than $800 \mathrm{~m}$ (using $2100 \mathrm{~m} / \mathrm{s}$ velocity). That depth, and the uncertainty of the thickness of section used to extrapolate the rhyolite aquifer below the basalt reflector, led to the abandonment of the original site north of the Boise River (Figure 1).

\section{Damage tests}

Boise city officials and local utility representatives required proof that no damage to city streets, buried utilities, or adjacent buildings would result from acquiring seismic data with a land air gun. Also, the noise component of the air gun was of concern due to off-hours acquisition through residential neighborhoods. The city selected a test site on a street where road resurfacing was scheduled and a cracked sewer line was buried at a depth of 1-2 m. Tests on unlined asphalt and concrete sidewalks (without a subbase) were also performed. The city ran a video camera in the sewer line, both before and after air-gun shots, to monitor any changes in the sewer's cement wall. A four-component (longitudinal, transverse, vertical, and

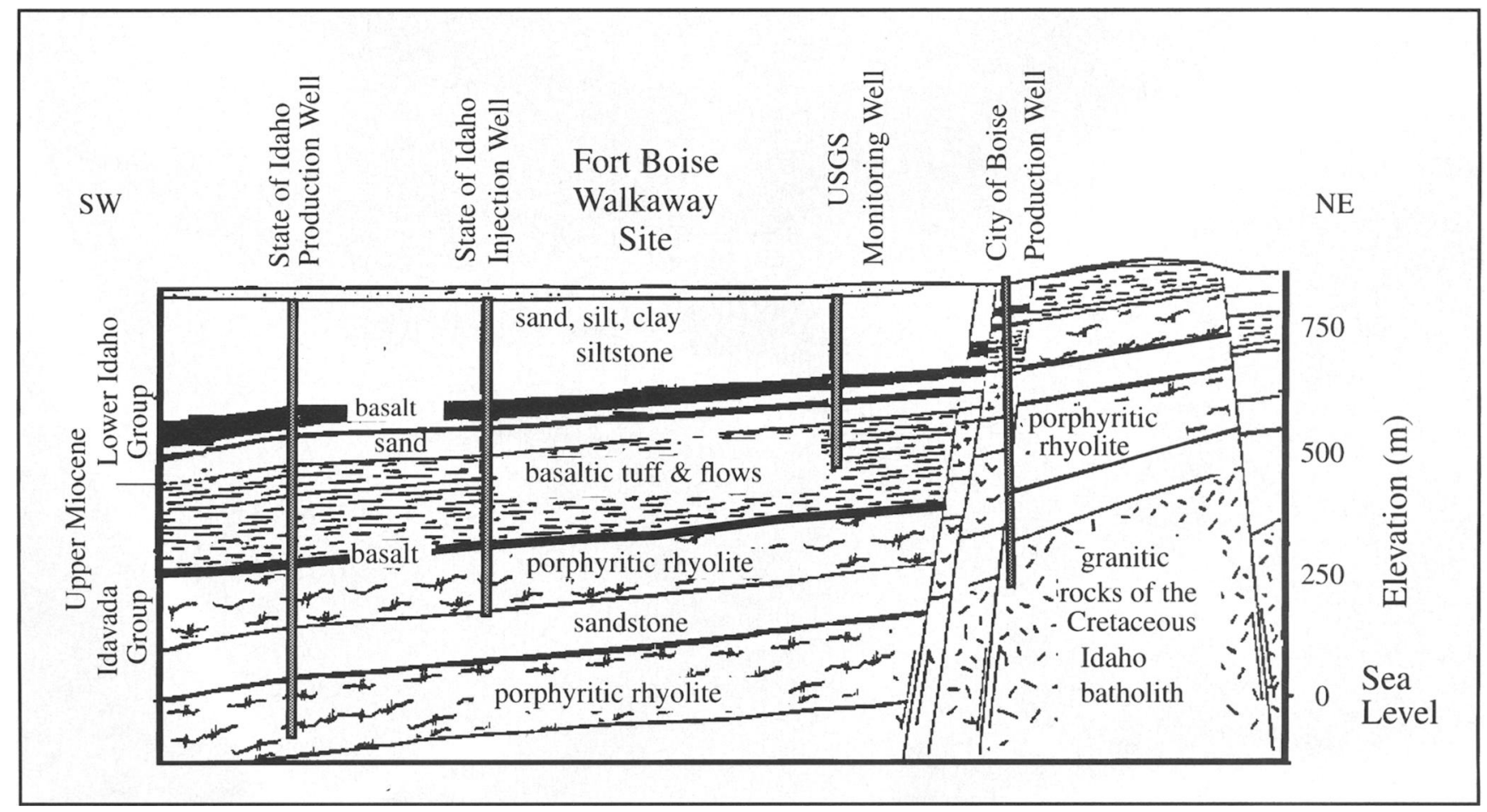

FIG. 2. Geologic cross section through downtown Boise based on local geothermal wells (from Burnham and Wood, 1985). The section has equal horizontal and vertical scales. The site for the Fort Boise walkaway seismic test is shown. 


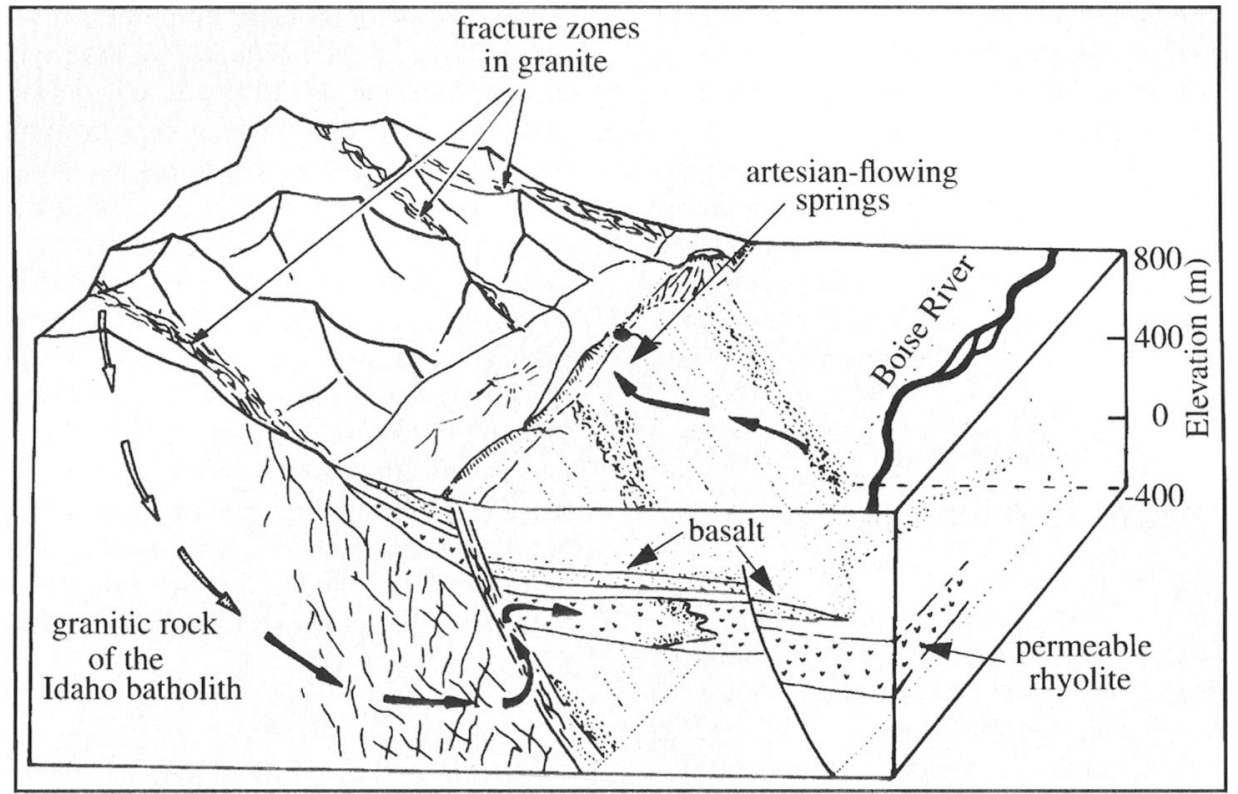

FIG. 3. Conceptual model (vertical and horizontal scales approximately equal) representing the local geothermal groundwater circulation system (modified from Wood and Burnham, 1987). Groundwater circulates through fractures in granite of the Idaho Batholith. Artesian pressure forces the geothermal water along zones of weakness (faults) until it is trapped by impermeable basalt overlying the permeable rhyolite units.
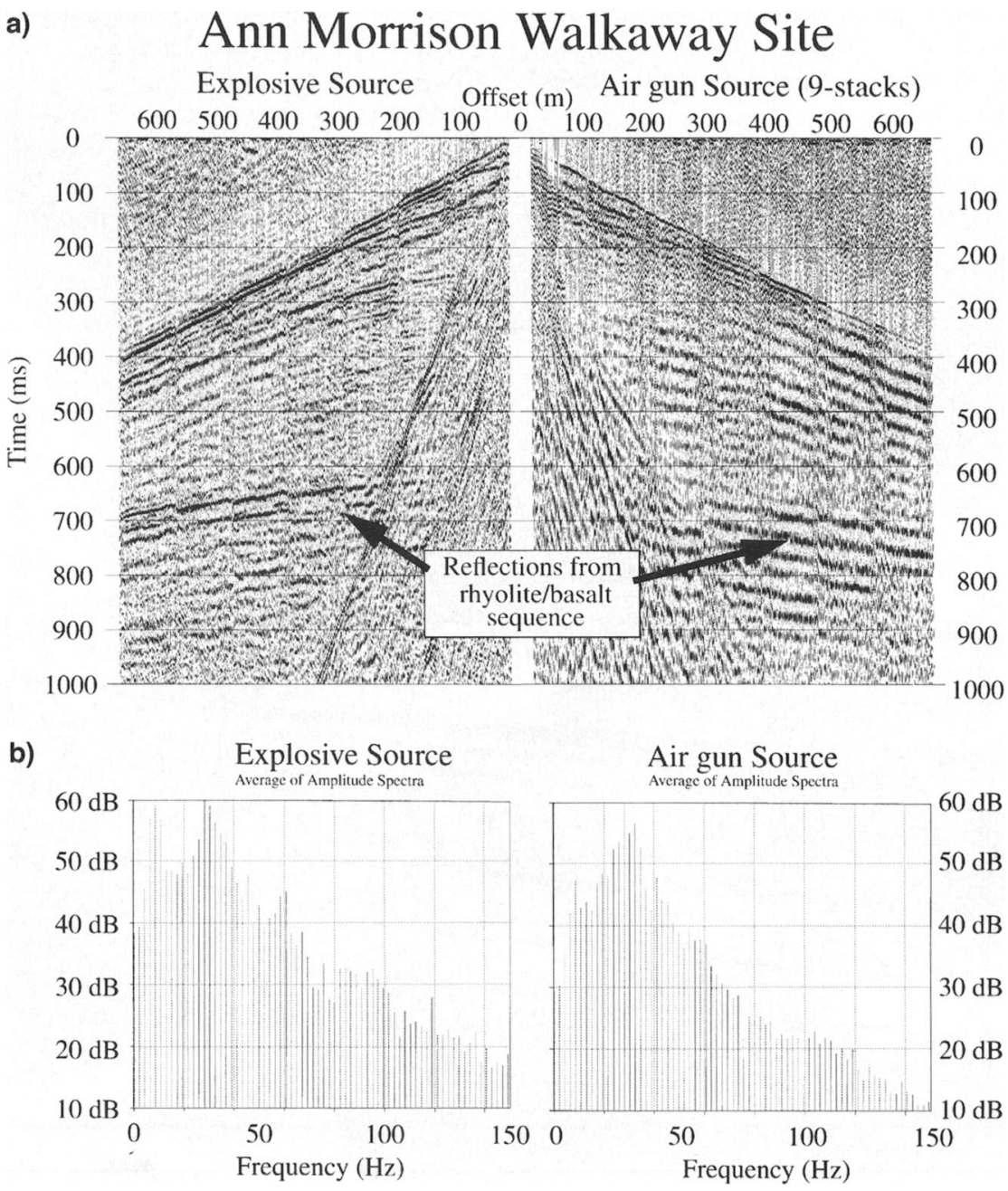

Fig. 4. (a) Comparison of buried explosive versus land air gun sources at Ann Morrison Park. Both sources produce adequate energy to image the target zone (up to $800 \mathrm{~m}$ depth). (b) Spectral analyses show the buried explosive source produces a broader reflection bandwidth than the air gun source. The frequency measurements are from a $400-850 \mathrm{~ms}$ window at $380-480 \mathrm{~m}$ offset. 
sound) blast vibration monitor was also used to measure peak particle velocities and sound pressure at various offsets from the air gun (Figure 5). These measurements were then compared to damage and noise level studies (Bollinger, 1971; Siskind et al., 1980; Konya and Walter, 1990) to assess the risk of structural damage to nearby buildings, buried objects, and the road surface (Figure 6). We tested the air gun at varying pressures (1500 and $2000 \mathrm{psi}$ ), chamber sizes (60 and 75 in $^{3}$ guns), and distances from the sewer line.

The tests demonstrated that little to no damage on roadgrade asphalt resulted after $2-4$ consecutive air-gun shots (with the 75 -in ${ }^{3}$ chamber), but small cracks appeared after 1-2 shots on unlined asphalt, concrete roadways, and sidewalks. We observed no change in the integrity of the sewer line with any combination of acquisition parameters, including the use of a $75-$ in $^{3}$ chamber with full pressure (2000 psi) directly over the cracked line at the shallowest site ( $1 \mathrm{~m}$ depth). The results of the blast vibration monitor suggest that the air gun could be safely deployed at distances as close as $5 \mathrm{~m}$ without probable damage to nearby structures. This was based on observed frequency and amplitude measurements of the peak particle velocity (Figure 6). Although frequencies decrease with in- creasing distances from the source (thus increasing the damage risk), particle velocity amplitudes also decrease. For distances of $5 \mathrm{~m}$, frequencies greater than $40 \mathrm{~Hz}$ were observed, placing damage probabilities below minor damage levels (Figure 6). Because particle velocities generally increase by a factor of three when distance is halved (Konya and Walter, 1990), we chose to maintain a conservative $5 \mathrm{~m}$ distance from any permanent structures or buried utilities with two air-gun shots per location (to reduce risk of surface cracking). Empirical studies (Bollinger, 1971) rate this distance as noticeable to unpleasant with respect to ground motion and sound pressure levels, but the air-gun source was generally operated at distances greater than $10 \mathrm{~m}$ from residential buildings and continually moving, therefore maintaining the curiosity of nearby residents without generating complaints.

\section{Seismic data acquisition}

After the walkaway and damage tests successfully demonstrated that the seismic reflection technique could determine depth to rocks associated with the geothermal aquifer within downtown Boise, two seismic reflection lines were acquired

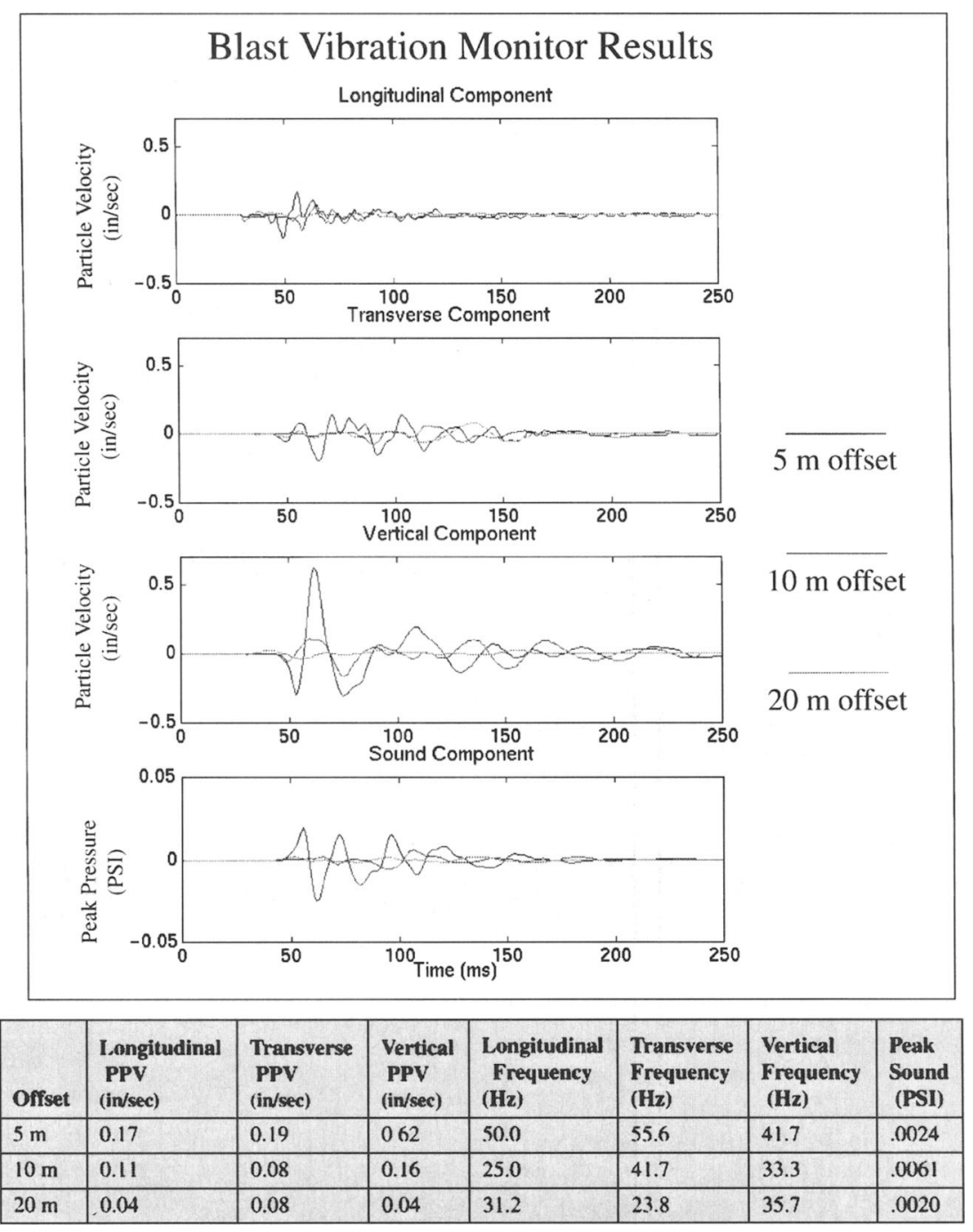

FIG. 5. Results from the blast vibration monitoring test. Note peak particle velocities (PPV) less than 1 in/s for all three components (longitudinal, transverse, and vertical) and frequencies exceeding $40 \mathrm{~Hz}$ at near offsets $(5 \mathrm{~m})$. Sound levels fall below any potential damage levels for distances greater than $5 \mathrm{~m}$ (Bollinger, 1971). 
(Figure 1) to determine the geologic structure. A 10-m source and receiver interval was selected to image within the reflection window for the estimated range of aquifer depths (from Figures 2 and 4) and to reduce the influence of ground roll energy on the final stack. Standard common midpoint acquisition techniques (Mayne, 1962) for shallow targets (e.g., Hunter et al., 1984; Steeples and Miller, 1990) were employed. At each shot point, 8 to 16 air-gun shots were recorded using a source array (moving the air-gun source one pad length after two shots). Individual shots records were summed for each station location to attenuate ambient noise (traffic, wind noise, etc.), ground roll, and increase the overall data quality.

The data were recorded using a 48-channel Bison 9048 seismograph with $10-\mathrm{Hz}$ geophones. We selected $10-\mathrm{Hz}$ geophones because of the relatively low-frequency nature of the air-gun source and the dynamic range of the Bison seismograph. Sandbags were placed on all geophones to further attenuate aircoupled noise and to help alert on-coming traffic to the geophone locations. Baseplates replaced spikes to couple with the asphalt surface. Shots were recorded on all stations except across the busiest streets. This provided nearly full 24 -fold coverage along the length of both profiles.

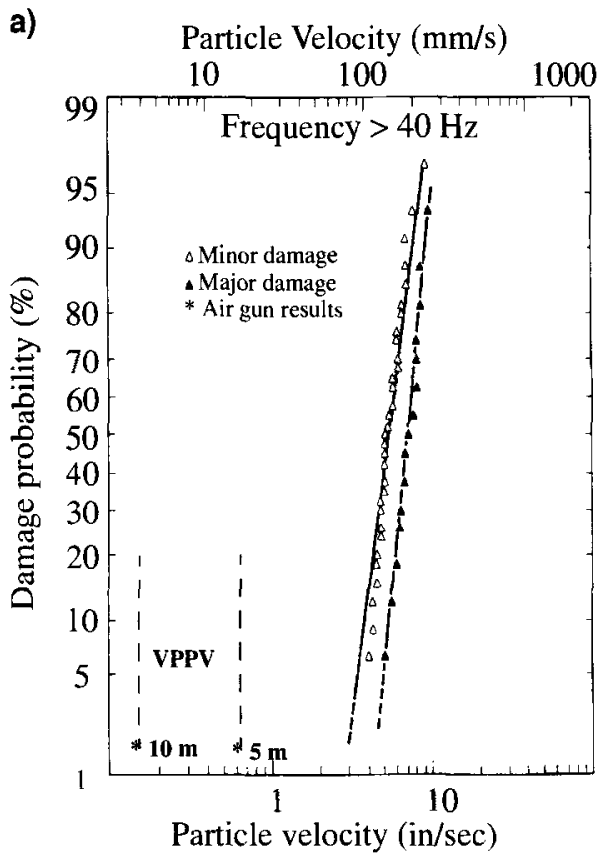

b)

\begin{tabular}{|l|l|}
\hline Minor damage & Major damage \\
\hline Loosening/Falling of Plaster & Structural weakening \\
\hline $\begin{array}{l}\text { Cracks in masonry around openings } \\
\text { near partitions. }\end{array}$ & Rupture of opening vaults \\
\hline Hairline to $3 \mathrm{~mm}$ cracks & Cracks several $\mathrm{mm}$ in walls \\
\hline Fall of loose mortar & Fall of masonry (e.g. chimneys) \\
\hline & Load support ability affected \\
\hline
\end{tabular}

FIG. 6. (a) A comparison of particle velocity with damage probability for frequencies greater than $40 \mathrm{~Hz}$. (b) Damage criteria. Note: (from Figure 5) frequency content for near offsets $(5 \mathrm{~m}$ ) is greater than $40 \mathrm{~Hz}$ for all components. Figure is modified from Siskind et al. (1980).

\section{Seismic data processing}

The data were checked for quality each day during and after field acquisition. Data were processed (summarized in Table 1) on a workstation using Landmark's ProMAX seismic processing package. Individual air-gun shots were summed into common shot gathers using an alpha-trimmed mean summing method. This method excluded $12.5 \%$ of the smallest and largest samples from individual shots and was preferred over a simple shot averaging process because of the large amount of ambient noise. Also, the alpha-trimmed method was superior to a diversity stack method (scaling by the inverse of the power) because of problems associated with our roll-along switch. Because of a wiring short, groups of channels dropped were occasionally on the raw shot records, thus providing very small amplitude signals on these channels. A diversity stack method would have amplified the dropped channels by an inverse scaling process, thus destroying the data quality for an entire common-shot record.

After stacking common-shot gathers, the data were processed to optimize the signal quality and remove coherent and random noise. Muting was applied to reduce surface waves, refractions, and waveguide reverberations. Trace edits, a bandpass filter, and spiking deconvolution also helped improve the signal quality. An iterative approach to velocity analyses and residual static corrections increased reflection coherency on the final stacks. Migration of the stacked seismic data was successful where full coverage was available. Artifacts from the migration process appeared where data quality suffered from acquisition and processing limitations.

\section{Reflection line 1}

Line 1 begins south of the Boise River on the campus of Boise State University (Figure 1). The survey line crosses Julia Davis Park, then follows 3rd Street through downtown Boise before terminating at the city's geothermal production wells. The state's injection well and the U.S. Geological Survey's monitoring well provide a tie to lithology along the profile.

The dominant feature on the unmigrated stack of line 1 (Figure 7) is a reflection that dips $\left(\sim 11^{\circ}\right)$ to the south, from 250 to $400 \mathrm{~ms}$ two-way traveltime ( $\mathrm{twtt}$ ) between Myrtle Street and Fort Street (event A). South of Myrtle Street, event A contains lower relative amplitudes, then dips north below Julia Davis Park with a bow-tie feature (crossing reflections) near the bend in the seismic line between Myrtle Street and the park. Event A shallows to the south near the Boise River and the line 2 intersection. North of Fort Street, reflections appear more discontinuous to absent, including event A. Additional reflections appear in the unmigrated seismic section both above and below event $\mathrm{A}$ throughout the section, but generally appear more discontinuous. The dip of these secondary reflectors is generally similar to event $A$.

A sonic log from the State of Idaho's geothermal injection well (along line 1) provides information to build a synthetic seismogram (Figure 8) to correlate lithology to the migrated seismic section. The expected arrival times of synthetic reflections from individual volcanic units associated with the geothermal aquifer match the observed arrivals. In particular, event $\mathbf{A}$ at the injection well site appears at approximately $260 \mathrm{~ms}$ twtt on the migrated seismic section and matches the 
calculated time to the upper contact of the shallowest basalt from the lower Idaho Group (Figure 2).

The bow-tie feature observed near Myrtle Street on the unmigrated section, the shallowing of event $A$ near the river, and the local decrease in reflection amplitudes associated with event $A$ (Figure 7 ) all suggest a fault zone may be present at this location. The migrated stack (Figure 9) shows event A as discontinuous south of Front Street, with a major decrease in reflector dip south of Myrtle Street. Although this is near a short bend in the seismic line, the significant drop in reflector depth cannot be accounted for with an eastward dip component because an apparent dip to the west is observed on line 2 (discussed below).

North of Fort Street, the seismic character of line 1 changes; a region of more discontinuous reflections is observed. This likely is caused by a zone of multiple fault strands in the section, as may be expected from a geothermal producing zone that is structurally controlled. This is consistent with the laterally varying aquifer depths observed in the geothermal wells and geologic mapping in the foothills north of the seismic line

Table 1. Processing flow for the seismic reflection data. The data were processed using Landmark's ProMAX processing system on a DEC UNIX workstation.

\begin{tabular}{|c|c|}
\hline Processing step & Description \\
\hline Data Input (Bison format) & $\begin{array}{l}\text { 10-m station spacing, air-gun source ( } 8-16 \text { stacks per station), } 10-\mathrm{Hz} \text { geophones, } \\
4-500-\mathrm{Hz} \text { field filters, and a } 1.0-\mathrm{ms} \text { sample rate }\end{array}$ \\
\hline Geometry & Acquired with a Topcon GTS-4A total station \\
\hline $\begin{array}{l}\text { Mean alpha-trim sum of } \\
\text { common shot records }\end{array}$ & $\begin{array}{l}\text { Excluded } 12.5 \% \text { of the smallest and largest samples before the } \\
\text { summing process }\end{array}$ \\
\hline Trace edits & Manually selected bad traces generated from system/cultural noise \\
\hline Amplitude recovery & Recover signal lost due to spherical divergence, scattering, and intrinsic attenuation \\
\hline Bandpass filter $(30-90 \mathrm{~Hz})$ & Removed noise outside of bandwidth of the air-gun source \\
\hline Spiking decon & Collapse the source wavelet \\
\hline Common midpoint (CMP) sort & Sort from source to midpoint gathers \\
\hline Bottom mutes & Remove dominant surface wave energy from the shot gathers \\
\hline Top mutes & Refraction and waveguide reverberation energy removal \\
\hline Elevation statics & Near-surface velocity correction to move seismic data to a flat datum \\
\hline Velocity analyses & Iterative analysis to optimize reflection coherence \\
\hline Residual statics corrections & Up to a 5-ms correction per trace to increase coherency in the stack \\
\hline $\begin{array}{l}\text { Normal moveout } \\
\qquad(\mathrm{NMO}) \text { correction }\end{array}$ & Applied NMO corrections based on optimum stacking velocities \\
\hline CMP ensemble stack & Sum common midpoints to simulate a cross-section profile \\
\hline F-K migration* & Places reflectors in proper spatial position on the stacked sections \\
\hline Amplitude gain (AGC) $-250 \mathrm{~ms}$ & Boost the signal from the dominant reflection package \\
\hline
\end{tabular}

*This step does not apply to unmigrated sections.

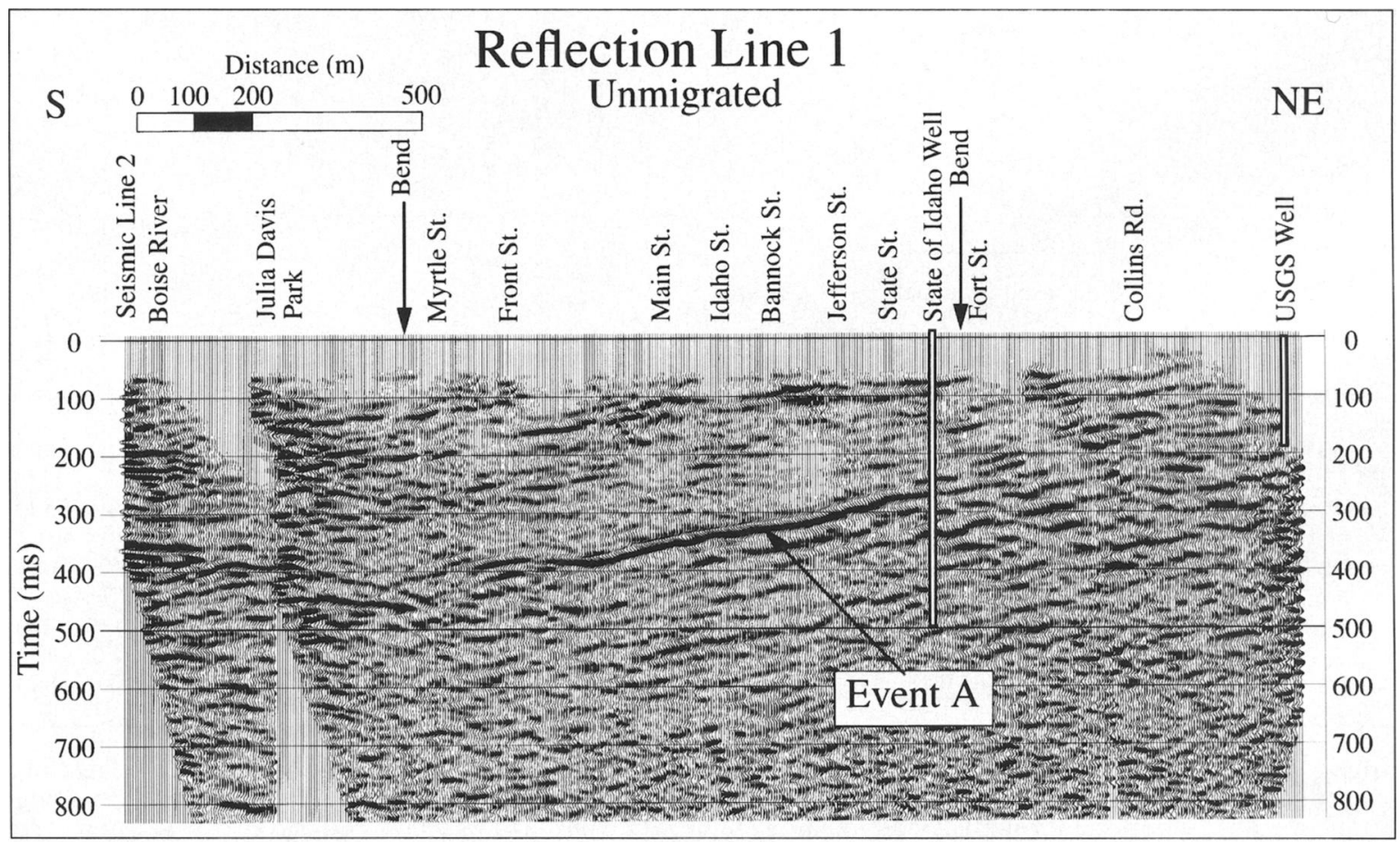

FIG. 7. Unmigrated image of line 1. This line extends from the Boise River north to the Boise range front. Note the large amplitude reflection package (event $\mathrm{A}$ ) dipping south through the downtown Boise region. The section has no vertical exaggeration for $2000 \mathrm{~m} / \mathrm{s}$ twtt. 


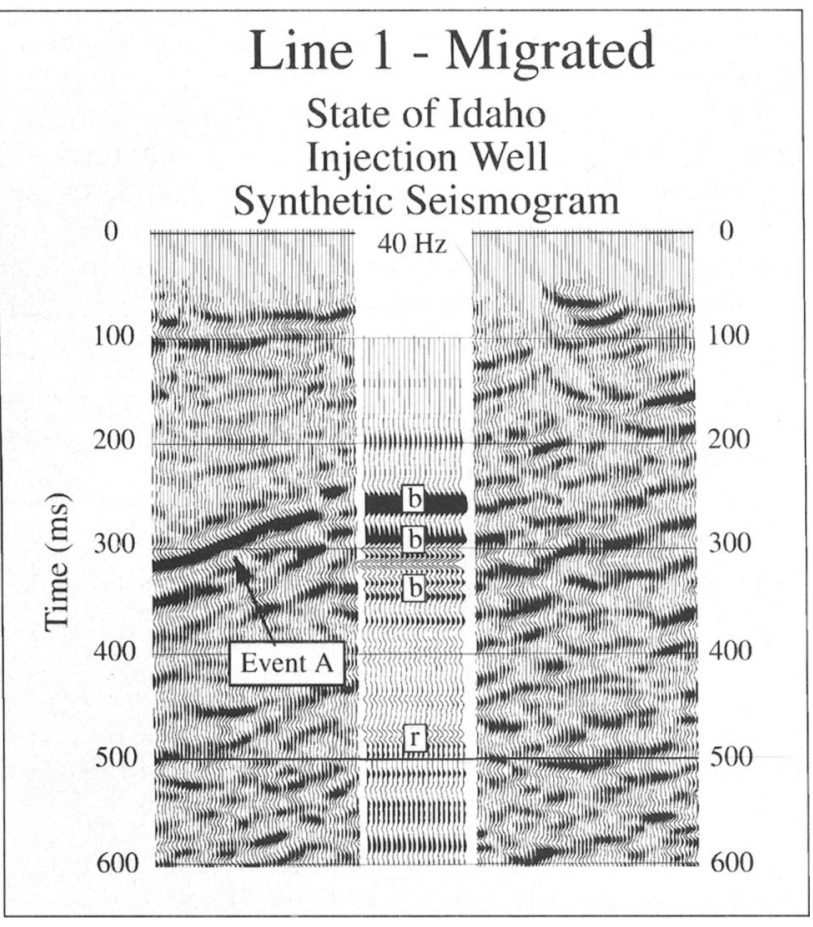

FIG. 8. Synthetic seismogram generated from the State of Idaho injection well's sonic log compared to the adjacent migrated seismic traces. The synthetic seismogram was calculated using a $40-\mathrm{Hz}$ wavelet. Marker volcanic units from the lithologic $\log$ are labeled: $b=$ basalt, $r=$ rhyolite. Note a strong correlation between the upper basalt unit and event $A$.
(Wood and Burnham, 1983). Although there are coherent reflections below the interpreted top of the volcanic sequence, the estimated depth to the upper rhyolite (the geothermal producing zone) is projected on the migrated seismic section (Figure 9) from the State of Idaho injection well. The extrapolated depth to the rhyolite contact is based on the assumption that the thickness and interval velocity to the upper basalt contact is relatively uniform to the south from the known lithology of the injection well.

\section{Reflection line 2}

Seismic line 2 (Figure 10) crosses the southern end of line 1, as shown in Figure 1. Line 2 parallels the Boise River and extends from a city park (Ann Morrison Park) to the campus of Boise State University. The line was acquired weekdays in the city park and on campus during the weekend. This strategy minimized the cultural noise along the profile and conformed to the permitting process. We were forced to skip shots and receivers on 9th Street and Capitol Boulevard because of heavy traffic.

A similar, strong-amplitude reflection package ties line 1 to line 2 (event A) and appears from 350 to $410 \mathrm{~ms}$ twtt east of 9 th Street and from 580 to $700 \mathrm{~ms}$ twtt west of 9 th Street. A decrease in the dominant frequency of event $A$ is observed below Ann Morrison Park compared to below Boise State University. Additional coherent reflections appear above the dominant reflection package. Signal quality did diminish in the vicinity of 9 th Street and Capitol Boulevard due to cultural noise, but reflections can still be traced across the section.

The dominant reflection on line 2 (event $A$ ) is interpreted as the basalt sequence in the lower Idaho Group (Figure 11).

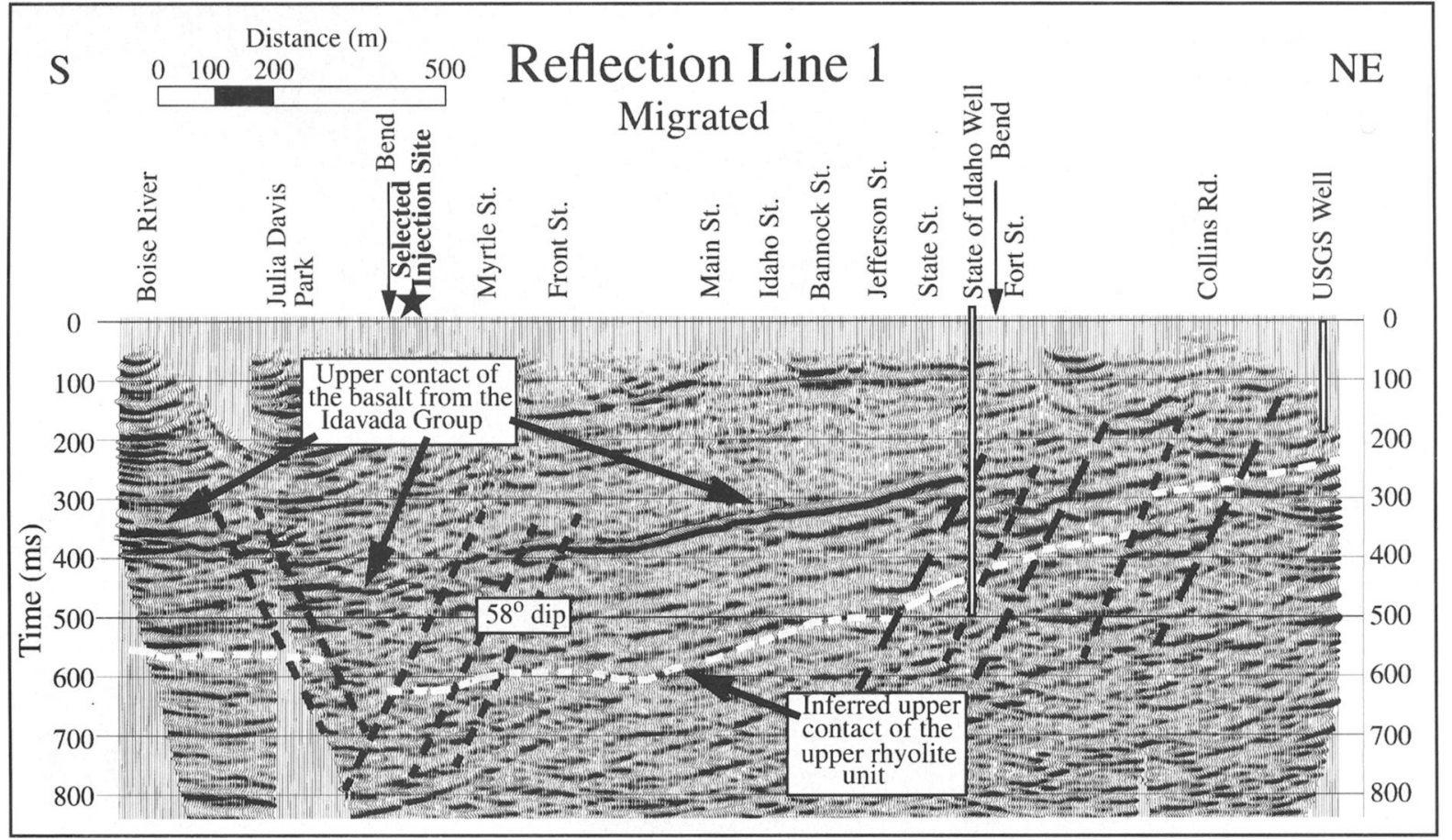

FIG. 9. Migrated north-south seismic line with interpretation. The selected site for the new injection well is located in a region with suspected faults in the geologic units associated with the geothermal aquifer. The estimated depth to the upper contact of the upper rhyolite member is projected from the depth recorded in the State of Idaho injection well and the assumption of a constant thickness volcanic assemblage. The section has no vertical exaggeration for $2000 \mathrm{~m} / \mathrm{s} \mathrm{twtt}$. 
A major offset fault $(\sim 200 \mathrm{~m})$ is interpreted west of 9 th Street and may be an extension of the northwest-trending Eagle-West Boise fault, originally mapped by Squires et al. (1992) northwest of downtown Boise. The fault orientation observed on the seismic data must trend north to northwest since fault offset of this magnitude is not observed along line 1 . The magnitude of offset does match that of the Eagle-West Boise fault (Squires et al., 1992).
The change in reflection character of event A across the fault may be associated with increased depth to the west, or may be due to a change in lithology of the overlying sedimentary sequence. The lithologic logs of the region suggest a change from a more coarse-grained sandstone dominated facies in the upper few hundred meters below Ann Morrison Park (to the depth of well logs in the region) compared to a finer grained mudstone facies north and east of the Eagle-West Boise fault (Squires

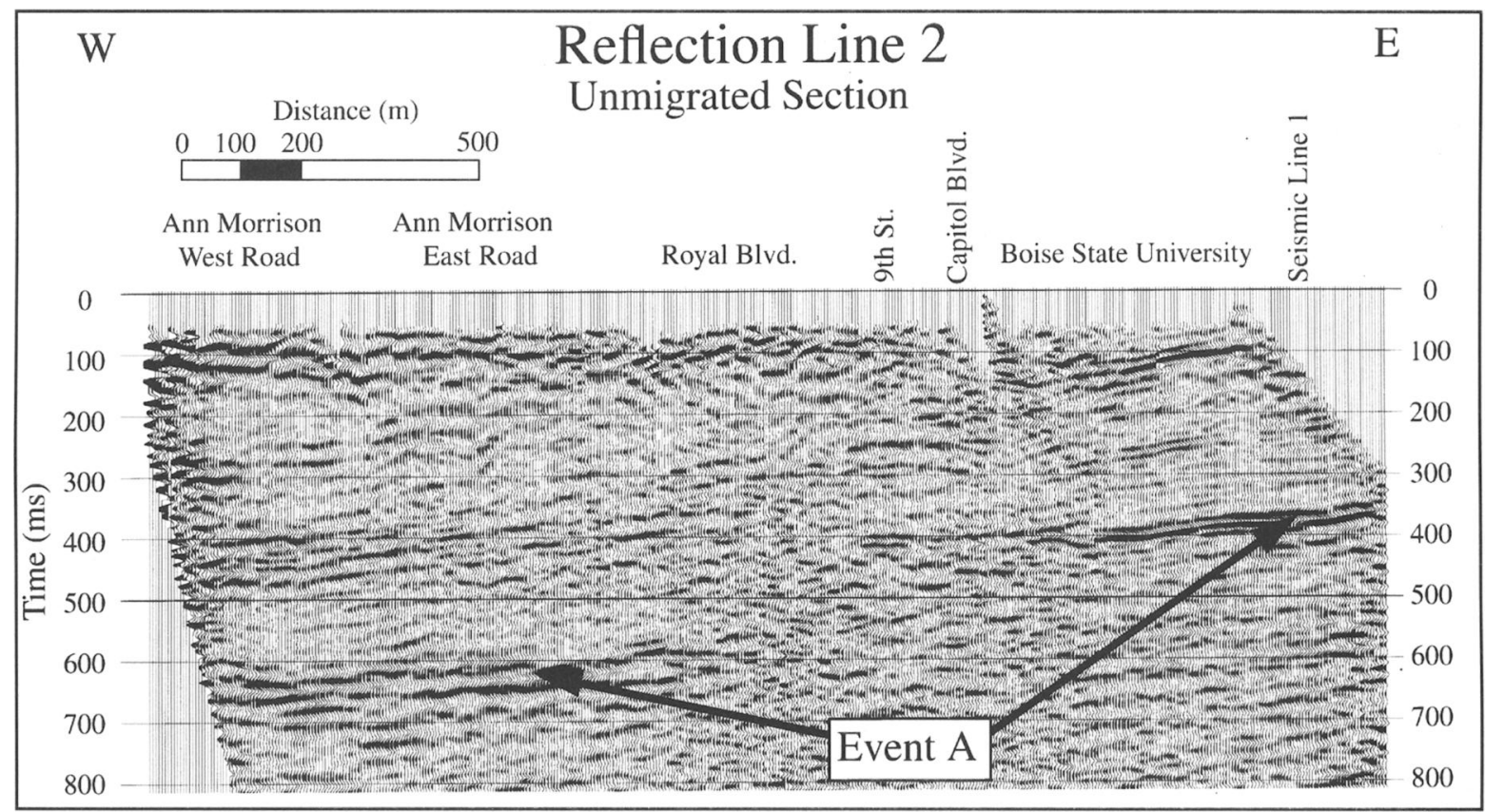

FIG. 10. Unmigrated image of line 2. Note the large-amplitude reflection package on the east and west portion of the image from 350 to $750 \mathrm{~ms}$. Also note the continuous reflectors above the large-amplitude discontinuous reflection package. The section has no vertical exaggeration for $2000 \mathrm{~m} / \mathrm{s} \mathrm{twtt}$.

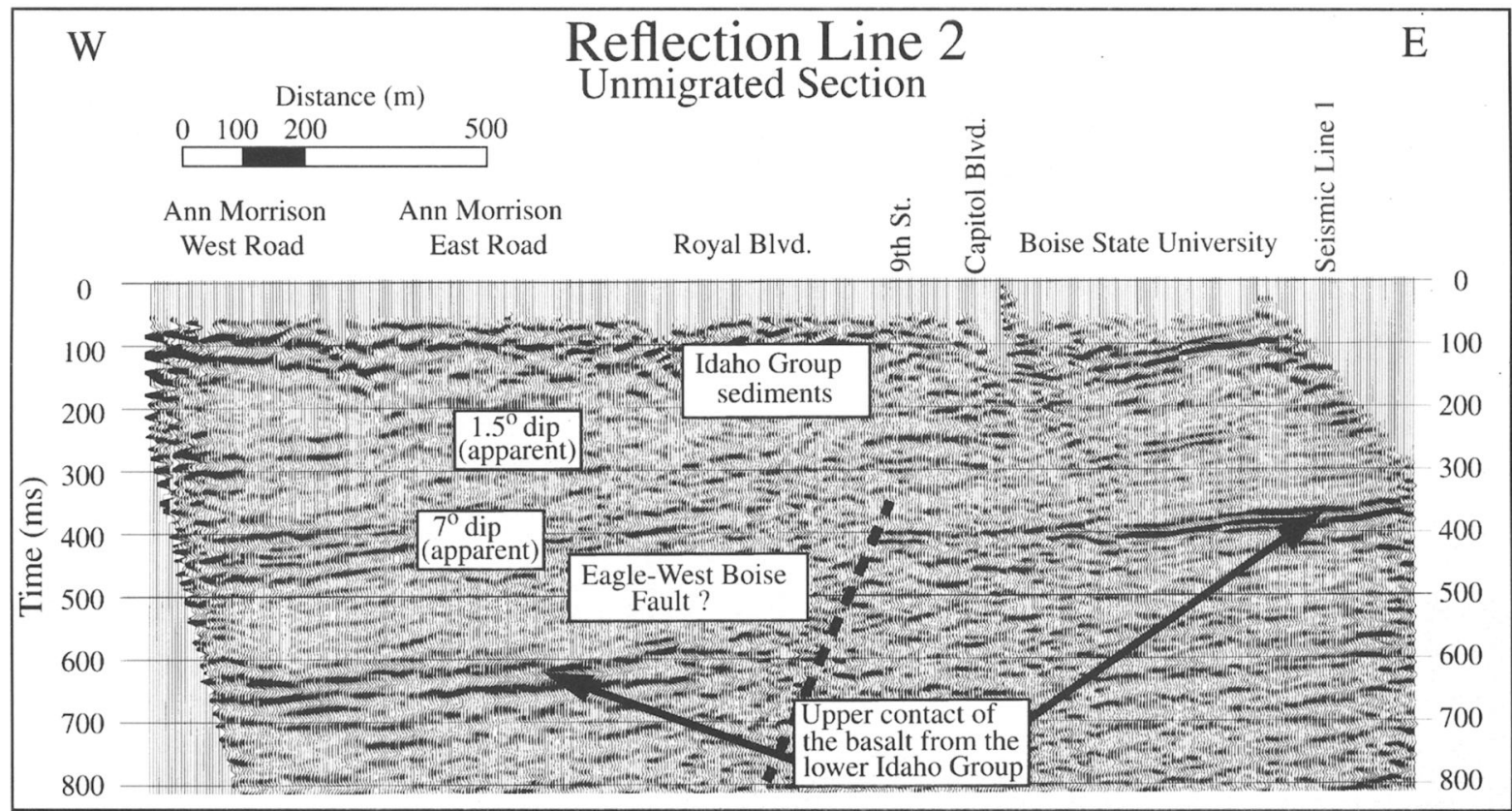

FIG. 11. Interpretation of unmigrated line 2 (migrated section not shown due to migration artifacts from the line ends). The upper contact of the basalt from the Idaho Group reflector is inferred from line 1 . The Eagle-West Boise fault is a feature seen on petroleum industry data acquired near Boise and appears in a road cut northwest of downtown. Apparent fault offset is approximately $200 \mathrm{~m}$ down to the west on the Eagle-West Boise fault. The section has no vertical exaggeration for $2000 \mathrm{~m} / \mathrm{s} \mathrm{twtt}$. 
et al., 1992). More steeply dipping reflections above event A suggest sedimentary downlap on the volcanic rock assemblage and are likely associated with interbedded lacustrine sedimentary deposits from a prograded prodelta typical in the Boise Basin (Wood, 1994). Reflections associated with these sediments do not appear offset by the Eagle-West Boise fault, suggesting the fault zone has not been active since deposition. A change in reflector dip in the sedimentary section on the west end of line 2 is also observed. This is likely sedimentary in origin.

\section{DISCUSSION}

Although the geometry of permeability within the geothermal aquifer is unknown, locating a zone of fractured volcanic rocks at a sufficient distance from the existing well field (to avoid cooler water breakthrough) provides the greatest probability of stabilizing the temperature and pressure in the aquifer. The city hopes to drill into a fractured zone in the rhyolite unit of the Idavada Group, where permeability is high enough to accept the spent water that will subsequently be reheated by percolation through the geothermal aquifer. The seismic results emphasize this correlation between fault zones and the location of existing geothermal wells. Although the state's geothermal wells were located by convenience, these wells (and the city and Veterans Affairs wells) likely induce circulation of geothermal water due to interconnected fracture permeability.

The depth to the geothermal aquifer and proximity to the hot-water distribution and collection system are also important cost considerations. Since the primary fault zone north of State Street is off-limits to exploration due to concerns of thermal impact to existing wells, a secondary fault zone is of interest. An advisory panel, convened by the City Public Works Department, jointly recommended placing the proposed injection well along line 1 south of Myrtle Street (Figure 1) in the interpreted fault zone shown on Figure 9.

A primary concern with locating the injection well north of the selected site was drilling into an unfractured, impermeable rhyolite, thus providing no disposal option for the spent water. If the rhyolite units are permeable, current production wells may be thermally impacted. To the south and west (along line 2), the geothermal aquifer appears deeper and the geology more continuous (no major fracture zones), except for the interpreted Eagle-West Boise fault on line 2 (Figure 10). This fault zone was not recommended for the injection site because of the increased depth to the aquifer, and the suspected northwest trend of the fault, thus decreasing the likelihood of interaction with the primary geothermal production zone. Also, the Eagle-West Boise fault acts as an impermeable boundary in the cold water aquifer (Squires et al., 1992). A similar condition in the geothermal aquifer would have defeated a primary goal of the injection well. Although the selected injection site is not along the current path of surface pipes, future potential customers are located nearby and extending the distribution system into this area may be economically justified.

\section{CONCLUSIONS}

The Boise geothermal seismic work demonstrates that the seismic reflection method with a land air gun is a viable, noninvasive technique for imaging near-surface targets in an urban environment. Cooperation with local authorities and adequate testing of seismic sources at end-member geologic sites prior to acquiring seismic reflection profiles ensured a safe project with a reasonable probability of success.

An injection well site was selected in a secondary fault zone outside the present geothermal well field based on the seismic results. The seismic methods provided data that helped optimize the site selection to stabilize pressure in the geothermal system, avoid thermal breakthrough of cooler injection into production wells, decrease drilling costs, and increase production of the geothermal heating system for future customers. If this secondary fault zone proves to be an active geothermal producing zone, more exploration is likely.

\section{NOTE ADDED IN PROOF}

During April 1998, drillers completed the injection well at the site selected from the seismic reflection results. The depth to the upper contact of the upper basalt was $468 \mathrm{~m}$ and the depth to the upper contact of the upper rhyolite unit was $635 \mathrm{~m}$. These depths correlate well with the observed two-way traveltimes from the seismic reflection experiment $(450 \mathrm{~ms}$ and $600 \mathrm{~ms}$, respectively) using an average velocity of $2100 \mathrm{~m} / \mathrm{s}$ (based on sonic $\log$ measurements from the State of Idaho well). Also, at present, the well is producing more than 2650 liters/minute of $76^{\circ} \mathrm{C}$ water without pumping, suggesting the rhyolite unit may be fractured.

\section{ACKNOWLEDGMENTS}

Funding for this project was provided by the U.S. Department of Energy and the City of Boise (cooperative agreement number DE-FC07-93ID13137). The author thanks the field crew involved in the acquisition of the seismic survey and the Boise geothermal advisory panel. Thanks to Jack Pelton, Spencer Wood, Harry Jol, and an anonymous reviewer for contributing to this document. CGISS contribution number 0072.

\section{REFERENCES}

Bollinger, G. A., 1971, Blast vibration analysis: Southern Illinois University Press.

Burnham, W. L., and Wood, S. H., 1985, Field trip guide for geology of the Boise geothermal system: 38th Ann. Mtg., Rocky Mountain Section, Geol. Soc. Am.

Clemens, D. M., and Wood, S. H., 1993, Radiometric dating, volcanic stratigraphy, and sedimentation in the Boise foothills, northeastern margin of the western Snake River Plain, Ada county, Idaho: Isocron/West, 59, 3-10.

Hunter, J. A., Pullan, S. E., Burns, R. A., Gagne, R. M., and Good, R. L., 1984, Shallow seismic reflection mapping of the overburdenbedrock interface with the engineering seismograph-Some simple techniques: Geophysics, 49, 1381-1385.

Konya, C. J., and Walter, E. J., 1990, Surface blast design: Prentice-Hall, Inc.

Mayne, W. H., 1962, Horizontal data stacking techniques: Geophysics 27, 927-938.

Rafferty, K., 1992, A century of service: The Boise Warm Springs Water District system: Geo-Heat Center Quarterly Bull., 14, No. 2, 1-5.

Siskind, D. E., Stagg, M. S., Kopp, J. W., and Dowding, C. H., 1980 , Structure response and damage produced by ground vibrations from surface blasting, U.S. Bur. Mines Report of Investigations 8896 .

Steeples, D. W., and Miller, R., 1990, Seismic reflection methods applied to engineering, environmental, and groundwater problems, in Ward, S., Ed., Geotechnical and environmental geophysics, 1, 1-30.

Squires, E., Wood, S. H., and Osiensky, J. L., 1992, Hydrogeologic framework of the Boise aquifer system, Ada County, Idaho: Idaho Water Resources Research Institute, Research Technical Report 1408-0001-G1559-06.

Wood, S. H., 1994, Seismic expression and geological significance of a lacustrine delta in Neogene deposits of the western Snake River Plain, Idaho: AAPG Bull, 78, 102-121.

Wood, S. H., and Burnham, W. L., 1983, Boise, Idaho geothermal system: Geothermal Resources Council, Transactions, 7, 215-223.

1987, Geologic framework of the Boise Warm Springs geothermal area, Idaho: Geol. Soc. Am. Centennial Field Guide, Rocky Mountain Section, 117-122. 